\title{
Behavior Analysis and Health: Survey and Analysis of Articles in Open Access Databases
}

\author{
Taís da Costa Calheiros ${ }^{1}$ \\ Programa de Pós-Graduação em Análise do Comportamento da Universidade Estadual de \\ Londrina, Londrina, PR, Brazil \\ Mariana Amaral \\ Programa de Pós-Graduação em Psicologia Experimental: Análise do Comportamento da \\ Pontificia Universidade Católica de São Paulo, São Paulo, SP, Brazil \\ Centro Universitário Filadélfia, Londrina, PR, Brazil \\ Márcia Cristina Caserta Gon \\ Departamento de Psicologia Geral e Análise do Comportamento da Universidade Estadual \\ de Londrina, Londrina, PR, Brazil \\ Áderson Luiz Costa Júnior \\ Departamento de Psicologia Clínica da Universidade de Brasília, Brasília, DF, Brazil
}

\begin{abstract}
In the face of criticism on the lack of a systematization of psychological practice in health, was aimed to present a systematic review in open access on-line databases and analyze the scientific articles analytical behavior, published between 2005 and 2014, in Health Psychology. Two procedures were made in VHL Psychology Brazil, specifically in the Index Psi Technical-Scientific Journals, the Scientific Electronic Library On-line and the Latin American and Caribbean Health Sciences Literature. In Collection 1, was used the search strategy "behavior analysis" AND health OR "behavioral medicine" OR "medical psychology", which terms should be included as "words" or "in all indexes". In Collection 2, was used "psychology" AND other terms referring to 45 specialties of Medicine, present in the "abstract". The Registration Form of Scientific Articles guided the quanti-qualitative analysis on the basis of seven items: reference, year of publication, type of study, objectives, participants, procedures and conclusions. The results suggested the applicability of Behavior Analysis to healthcare, although the number of recovered items has been restricted due to conceptual and methodological obstacles. A need was seen to approach the analysis criteria of these materials by Information Science and Behavior Analysis professionals.
\end{abstract}

Keywords: Health Psychology, Behavioral Medicine, Literature Review.

\section{Análise do Comportamento e Saúde: Levantamento e Análise de Artigos em Bases de Acesso Livre}

\section{Resumo}

Diante das críticas à falta de sistematização da prática psicológica na área da saúde, objetivou-se apresentar uma revisão sistemática em bases de dados on-line de acesso livre e analisar artigos científicos analítico-comportamentais, publicados entre 2005 e 2014, na área da Psicologia da Saúde. Foram feitos

Mailing address: Universidade Estadual de Londrina, Departamento de Psicologia Geral e Análise do Comportamento, Rodovia Celso Garcia Cid (PR 445), Km 380, CEP 86057-970, Caixa Postal 10011, Londrina, PR, Brazil. Fone: +55 433371-4203 / +55 439831-1111. E-mail: calheirostais@gmail.com.

Financing: Coordination for the Improvement of Higher Level Personnel (CAPES) and Fundação Araucária. 
dois procedimentos na Biblioteca Virtual em Saúde (BVS) - Psicologia Brasil, especificamente no Index Psi Periódicos Técnico-Científicos, na Scientific Electronic Library On-line e na Literatura LatinoAmericana e do Caribe em Ciências da Saúde. Na Coleta 1, foi utilizada a estratégia de busca "análise do comportamento" AND saúde $O R$ "medicina do comportamento" $O R$ "psicologia médica", cujos termos deveriam constar como "palavras" ou "em todos os índices". Na Coleta 2, utilizou-se "psicologia" AND outros termos referentes a 45 especialidades da Medicina, presentes no "resumo". A Ficha Cadastral dos Artigos Científicos orientou a análise quanti-qualitativa em função de sete itens: referência, ano de publicação, tipo de estudo, objetivos, participantes, procedimentos e conclusões. Os resultados sugeriram a aplicabilidade da Análise do Comportamento à área da saúde, ainda que o número de artigos recuperados tenha sido restrito devido a entraves conceituais e metodológicos. Verificou-se a necessidade de aproximação dos critérios de análise desses materiais pelos profissionais da Ciência da Informação e da Análise do Comportamento.

Palavras-chave: Psicologia da Saúde, Medicina do Comportamento, Literatura de Revisão.

\section{Análisis del Comportamiento y Salud: Levantamiento y Análisis de Artículos en Bases de Datos de Acceso Abierto}

\section{Resumen}

Este estudio tuvo como objetivo presentar una revisión sistemática en las bases de datos on-line de acceso abierto y analizar artículos científicos analítico-comportamentales, publicados entre 2005 y 2014 , en la Psicología de la Salud. Dos procedimientos fueron realizados en la Biblioteca Virtual en Saúde (BVS) Psicología Brasil, específicamente en el Index Psi Revistas Técnico-Cientificas, en la Scientific Electronic Library On-line y en la Literatura Latinoamericana y del Caribe en Ciencias de la Salud. En la Recolecta 1, fue utilizada la estrategia de busca "análisis del comportamiento" $A N D$ salud $O R$ "medicina del comportamiento" OR "psicología médica", cuyos términos deberían constar como "palabras" o "en todos los índices". En la Recolecta 2, se utilizó "psicología" AND otros términos referentes a 45 especialidades de la Medicina, presentes en los "resúmenes". El análisis cuanti-cualitativo constó de siete ítems: referencia, año de publicación, tipo de estudio, objetivo, participante, procedimientos y conclusiones. Los resultados sugirieron la aplicabilidad del Análisis del Comportamiento en el área de la salud, aunque el número de artículos recuperados haya sido restricto debido a los obstáculos metodológicos y conceptuales. Se verificó a necesidad de aproximación de los criterios de análisis de esos materiales por profesionales de la Ciencia de la Información y del Análisis del Comportamiento.

Palabras-clave: Psicología de la Salud, Medicina del Comportamiento, Literatura de Revisión.

The Health Psychology, a field of scientific contributions and specific professional psychology, has its objectives centralized on the promotion and maintenance of health, prevention and treatment of diseases and disorders in normally healthy people (Matarazzo, 1980). This specialty features an educational, multidisciplinary and interdisciplinary nature, directed at the identification of etiologies and diagnoses related to health, diseases and disorders as well as the analysis of improvements and regulation in the health care system and the formation of public policy. Such interventions need to generate knowledge that solve problems in the health system, including both the relationship between behavior and health as well as the improvement of human resources and health institutions (Costa, 1997).

Occasionally, terms like Clinical Psychology and Health, Psychosomatic Medicine, Health Psychology (Kerbauy, 2002) and erroneously Clinical Psychology (Castro \& Bornholdt, 2004) are used to refer to the same sub-area, indicating a recurring confusion of terminology, with problematic names and based on different 
theoretical frameworks (Kerbauy, 2002). Either way, the health psychologist should be understood as a professional that deals with problems related to the health/disease continuum, regardless of the space in which it is inserted (Miyazaki \& Amaral, 1995), with the primary functions being to assist in the understanding of the relationship between behavior and health (Costa, 1997) and foster the establishment of cooperative relations between the patient, family and healthcare team (Federal Council of Psychology, 2006).

Several psychological approaches are part of the teaching, research and intervention field known as the Health Psychology. Since the beginning of the development of this area, Behavioral Analysis has empirically demonstrated significant contributions to the understanding of the factors related to the development of diseases, the promotion and maintenance of health behaviors and to behavioral modification of risk in different contexts (Jenkins, 2003/2007). In that approach, behavior is seen as a determining factor in the health-disease process and, as such, behavioral interventions involving individuals and groups can be planned with promotional, prevention and treatment objectives (Straub, 2005). Those interventions are directed to events related to the occurrence of behavior, whether a class of antecedent or consequential stimuli.

In Brazil, psychological interventions in health care have gradually become guided in scientific knowledge, with a specific training for that professional practice being indispensable (Castro \& Bornholdt, 2004). From that perspective, psychologists and behavior analysts in particular, need to refine training for complex skills that allow them to act effectively in providing services and/or research activities, and safeguarding all the due distinctions between applied research and the services provided directly to the population in the health arena (Johnston, 1996).

Part of that knowledge is derived from contact with the scientific production in the area, which provides the theoretical and practical model that must support the professional's actions. Once there was a marked restructuring in publishing media with the advent of the Internet, that is now characterized as one of the most accessible sources of technical and scientific information that can support work in Psychology (Packer, 2005).

This change provoked impacts on different instances of cyberspace, which are also linked to the political dimension of this disclosure: knowledge becomes recommended as well as public, and open access movements are strengthening (Packer, 2005). In this sense, the Virtual Health Library - Psychology (BVS - Psi Brazil) is an example of the national literature publication control project in Psychology, ${ }^{2}$ geared towards the efficient and rapid recovery of technical and scientific information with universal and equitable access. That type of initiative is advantageous because greater accessibility to databases like that makes it possible to get closer to all the scientific knowledge professionals that must sustain their works. That initiative will include a great deal of the psychologists, as they are already found from universities (e.g., $87.8 \%$ in Paraná), according to a survey done by the Regional Council of Psychology in the $8^{\text {th }}$ Region (2010). Because they are not embedded in academia, those professionals generally lack access to restricted databases, whose publications are more numerous and tend to study factors that go beyond diseases (Witter, 2008). Many of those publications are available in foreign languages, which can also influence the inquiry made by several of those professionals.

Considering the peculiarities observed in the current scientific publishing, critical of the lack of systematized psychological practices in medical environments (Costa et al., 2012; Gorayeb \& Guerrelhas, 2003), the notion of the historical challenges faced by psychologists in relation to vocational training, integration and corresponding to the expectations of the health labor market (Glueckauf, 1999; King, 2006; Matarazzo, 1982; McNamara, 1981) and the recognition that behavioral interventions generate a health condition through treatments with an advantageous cost-benefit and effective relation (Kaplan, 1990), investigating the Brazilian

Retrieved from http://www.bvs-psi.org.br/php/ level.php?lang $=$ pt\&component $=19 \&$ item $=30$ 
scientific production of behavior analysts in the Health Psychology available in open access databases is understood as being relevant. The aim is to present and discuss characteristics of recent studies on behavior analytic foundations that are available to all professionals of Psychology, enabling closer relations between the medical field and this psychological system, in addition to favoring the activities under a research-based unified perspective on behavior and health (Pomerleau, 1979; Reid, 1991; Smith, Kendall, \& Keefe, 2002), with more effective practices to the demands of assistance.

Hence, this research looks to: (a) present the process of executing a systematic review from free access on-line databases; and (b) analyze the analytic-behavioral scientific articles related to the Health Psychology area published between 2005 to 2014. Specifically, in the latter case, it was devoted to: finding scientific articles, quantifying them by publication year and analyzing them as the type of study, objectives, procedures, participants, in the case of applied or experimental research, and conclusions.

\section{Method}

This work consists of a systematic review, which is characterized by the meeting and evaluation process of several researches in a critical and succinct way (Costa \& Zoltowski, 2014). This rigorous synthesis of literature is necessary due to the continuous flow of information that is published and interferes in the process of health professionals' decision making as well as the limited time of those, which has created the need for developing concise studies (Galvão, Sawada, \& Trevizan, 2004).

\section{Instrument}

The Registration Form of Scientific Articles establishes the criteria for the collection, tabulation and analysis of the data, consisting of seven items, six of which correspond to the study variables for quantitative and qualitative analysis of this systematic review, namely: Reference, Publication Year, Type of Study, Objectives, Participants, Procedures and Conclusions.

\section{Procedure}

Selection of Databases. Remote access was granted to sources cited in Notice n. 001/2013 of the Ministry of Education (2013), in regrads to updating of the WebQualis criteria for the psychology area. That document was obtained by consulting the Qualis criteria by area, by selecting Psychology as an assessment area and the period corresponding to the year 2011, by virtue of the document relating to the classification of 2012 year not being yet available at the time of query. All the sources of data listed were consulted for the verification of free access.

The BVS is a virtual space coordinated and implemented by the Latin American and Caribbean Center for Information on Health Sciences (BIREME) under the leadership of the Pan American Health Organization (PAHO) / World Health Organization (WHO). It seeks to integrate the technical and scientific information produced in health sciences and develop a control of Brazilian scientific publications in Psychology (Packer, 2005). In that context, it was hypothesized that the academic and professional community area routinely consult concise and quality jobs, as indexed in the BVS, which determined the selection of that source of data.

However, because BVS-Psi Brazil incorporates several other bases, three databases were selected to carry out the data collection of this review, those being: Index Psi Technical-Scientific Journals, Scientific Electronic Library On-line (SciELO) and Latin American and Caribbean Health Sciences Literature (LILACS). Each of which consists of one of three types of databases within BVS-Psi Brazil: the first is a database of scientific papers nationwide that contain references with abstracts, the second is an electronic database with full text, and the third is a publications index of Health Sciences, whose records are indexed in Google.

The language chosen was Portuguese, hypothesizing the query made by professionals and students in the area who do not have the mastery to read in a foreign language. It is understood that, although that criterion is not necessarily related to the professional or academic competence of these individuals, nor even have a correlation 
with the quality of the undertaken interventions, it is known that contact with international references are restricted to specific institutions and populations as well as with the learning of other languages. Therefore, those factors may restrict the literature and not characterize what has been directing the training and the work of scholars and psychologists.

Selection of the Descriptors. The BVS-Psi Brazil offers the controlled vocabulary Health Sciences Descriptors (DeCS), which was used as the standard for the selection of descriptors used in that research. Pellizzon (2004, p. 153) states that the "use of a structured vocabulary allows the researcher to recover information with the exact term used to describe the content of that scientific document". Therefore, the descriptors are essential for the processing of the review, acting as a filter between the terminology of an area and the author's language.

It was however necessary to build a list of terms that would help to limit the scope of the literature to be studied (Luna, 2007). A list of keywords used in scientific work of reference authors in Behavior Analysis ${ }^{3}$ was drawn up that they produce on topics related to the Health Psychology, without that those were necessarily part of the set of accurate descriptors of the DeCS.

Initially, the insertion of keywords "functional analysis" and "behavior therapy" in the BVS-Psi Brazil was done between quotation marks and isolated, in order to retrieve works that made use of those terms. Since then, the first author registered the DeCS Descriptors and Psi Portuguese Descriptors of works pertaining to the interface of interest. As a result, all those terms were inserted in DeCS based on the following criteria: the selected language was "Portuguese" and in a query by word, the option "Exact Descriptor" was selected, preventing studies being picked with only one of the terms

This relationship of renowned behavior analysts in the sub-field investigated was obtained by adding the combination "behavior analysis" AND health in the advanced search field by subject in the CAPES Portal of Periodicals and by the refinement of the results by author, in consultation with the Currículo Lattes (http://www.cnpq/br). or words that compose the descriptor. In the query by index, an exchanged index was elected, as that enables whether the word exists in the DeCS and globally view all descriptors that they have, regardless of the position of the same in the term (Pellizzon, 2004).

The terms registered in the initial list and found as accurate descriptors in the DeCS were "behavior", "behavioral therapy", "behavioral medicine", "medical psychology" and "health". The terms "behavioral medicine", "behavior analysis", "health psychology", "applied behavior analysis" and "functional analysis" were not found as exact descriptors in that controlled vocabulary. Depending on the scope of the term "behavior" and "behavioral therapy", those were discarded. The descriptor "health" was kept to refine searches in combination with other words. The three remaining descriptors have been entered in the database by means of different combinations drawn from a hypothesis of association among variables (Volpato, 2007), with the use of the Boolean operands AND and OR. The keyword "behavior analysis" was added to the remaining descriptors, as they refer to the approach that should be included in the retrieved work, but it has not yet been located in the DeCS. To delimit the procedure, the number of works recovered in each combination and relevance of the results obtained in relation to the subject of that review has been verified.

Data Gathering. Data gathering procedures were performed in the period from 01/07/2015 to $05 / 07 / 2015$. The year of publication was added by including the AND and each period from 2005 to 2014, regardless of the combinations used in each data collection.

Data gathering 1. The combination "behavior analysis" AND "health" OR "behavioral medicine" OR "medical psychology" was chosen as appropriate for that study, since this would hypothetically tend to restrict the results for the sub-area of interest, avoiding the retrieval of behavior-analytic production in way that was excessively expanded and alien to the proposed objective way. That procedure is known as Collection 1 and the terms of the combination should be included as "words" or "in all indices" in the works. 
Data gathering 2. After confirmation of the retrieved material, it was observed that the results did not include renowned behavior analysts publications in the sub-area already mentioned. Therefore, this survey would be incomplete. A new search procedure was delimited with maintaining the association between technical variables, but including terms relating to medical specialties, plus the "psychology" keyword, and the terms that made those combinations must be included in the "summary". The term "behavior analysis" was removed from the strategy in the light of null results in Collection 1.
The identification of medical specialties was made possible by consulting Resolution of the Federal Council of Medicine n. 2.005/2012, which features the 53 medical specialties (2012). The inclusion of those specialties in the procedure in question was carried out in order to locate behavior analysts works that produce knowledge interfaced with the Medicine. The 53 specialties have been aggregated into 45 areas and terms combined with keyword "psychology" corresponded to the name of the area and/or another word concerning its subject matter, with the addition of the Boolean AND operand. All combinations that made up the Collection 2 procedure are described in Figure 1.

\begin{tabular}{|c|c|c|c|}
\hline \multirow{2}{*}{$\begin{array}{c}\text { Medical Specialty } \\
\text { Acupuntura }\end{array}$} & \multicolumn{3}{|c|}{ Search Strategies } \\
\hline & Psicologia & AND & Acupuntura \\
\hline Alergia e Imunologia & Psicologia & AND & Alergia \\
\hline & Psicologia & AND & Imunologia \\
\hline Anestesiologia & $\begin{array}{l}\text { Psicologia } \\
\text { Psicologia }\end{array}$ & $\begin{array}{l}\text { AND } \\
\text { AND }\end{array}$ & $\begin{array}{l}\text { Anestesiologia } \\
\text { Anestesia }\end{array}$ \\
\hline Angiologia & $\begin{array}{l}\text { Psicologia } \\
\text { Psicologia }\end{array}$ & $\begin{array}{l}\text { AND } \\
\text { AND }\end{array}$ & $\begin{array}{l}\text { Angiologia } \\
\text { Vascular }\end{array}$ \\
\hline Cancerologia & $\begin{array}{l}\text { Psicologia } \\
\text { Psicologia }\end{array}$ & $\begin{array}{l}\text { AND } \\
\text { AND }\end{array}$ & $\begin{array}{l}\text { Cancerologia } \\
\text { Câncer }\end{array}$ \\
\hline Cardiologia & $\begin{array}{l}\text { Psicologia } \\
\text { Psicologia }\end{array}$ & $\begin{array}{l}\text { AND } \\
\text { AND }\end{array}$ & $\begin{array}{l}\text { Cardiologia } \\
\text { Coração }\end{array}$ \\
\hline Cirurgia & Psicologia & AND & Cirurgia \\
\hline Clínica Médica & Psicologia & AND & Clínica AND Médica \\
\hline Coloproctologia & Psicologia & AND & Coloproctologia \\
\hline Dermatologia & Psicologia & AND & Dermatologia \\
\hline Endocrinologia e Metabologia & $\begin{array}{l}\text { Psicologia } \\
\text { Psicologia }\end{array}$ & $\begin{array}{l}\text { AND } \\
\text { AND }\end{array}$ & $\begin{array}{c}\text { Endocrinologia } \\
\text { Metabologia }\end{array}$ \\
\hline Endoscopia & Psicologia & AND & Endoscopia \\
\hline Gastroenterologia & Psicologia & AND & Gastroenterologia \\
\hline Genética Médica & $\begin{array}{l}\text { Psicologia } \\
\text { Psicologia }\end{array}$ & $\begin{array}{l}\text { AND } \\
\text { AND }\end{array}$ & $\begin{array}{c}\text { Genética AND Médica } \\
\text { Genética }\end{array}$ \\
\hline Geriatria & Psicologia & AND & Geriatria \\
\hline Ginecologia e Obstetrícia & $\begin{array}{l}\text { Psicologia } \\
\text { Psicologia }\end{array}$ & $\begin{array}{l}\text { AND } \\
\text { AND }\end{array}$ & $\begin{array}{c}\text { Ginecologia } \\
\text { Obstetrícia }\end{array}$ \\
\hline Hematologia e Hemoterapia & $\begin{array}{l}\text { Psicologia } \\
\text { Psicologia }\end{array}$ & $\begin{array}{l}\text { AND } \\
\text { AND }\end{array}$ & $\begin{array}{l}\text { Hematologia } \\
\text { Hemoterapia }\end{array}$ \\
\hline Homeopatia & Psicologia & AND & Homeopatia \\
\hline Infectologia & Psicologia & AND & Infectologia \\
\hline
\end{tabular}




\begin{tabular}{|c|c|c|c|}
\hline Medical Specialty & & ch Strat & \\
\hline Mastologia & Psicologia & AND & Mastologia \\
\hline Medicina de Família e Comunidade & $\begin{array}{l}\text { Psicologia } \\
\text { Psicologia }\end{array}$ & $\begin{array}{l}\text { AND } \\
\text { AND }\end{array}$ & $\begin{array}{c}\text { Medicina AND Família } \\
\text { Medicina AND Comunidade }\end{array}$ \\
\hline Medicina do Trabalho & Psicologia & AND & Medicina AND Trabalho \\
\hline Medicina de Tráfego & Psicologia & AND & Medicina AND Tráfego \\
\hline Medicina Esportiva & Psicologia & AND & Medicina AND Esportiva \\
\hline Medicina Física e Reabilitação & $\begin{array}{l}\text { Psicologia } \\
\text { Psicologia }\end{array}$ & $\begin{array}{l}\text { AND } \\
\text { AND }\end{array}$ & $\begin{array}{c}\text { Medicina AND Física } \\
\text { Medicina AND Reabilitação }\end{array}$ \\
\hline Medicina Intensiva & Psicologia & AND & Medicina AND Intensiva \\
\hline Medicina Legal e Perícia Médica & $\begin{array}{l}\text { Psicologia } \\
\text { Psicologia }\end{array}$ & $\begin{array}{l}\text { AND } \\
\text { AND }\end{array}$ & $\begin{array}{l}\text { Medicina AND Legal } \\
\text { Perícia AND Médica }\end{array}$ \\
\hline Medicina Nuclear & Psicologia & AND & Medicina AND Nuclear \\
\hline Medicina Preventiva e Social & $\begin{array}{l}\text { Psicologia } \\
\text { Psicologia }\end{array}$ & $\begin{array}{l}\text { AND } \\
\text { AND }\end{array}$ & $\begin{array}{l}\text { Medicina AND Preventiva } \\
\text { Medicina AND Social }\end{array}$ \\
\hline Nefrologia & Psicologia & AND & Nefrologia \\
\hline Neurocirurgia & Psicologia & AND & Neurocirurgia \\
\hline Neurologia & Psicologia & AND & Neurologia \\
\hline Nutrologia & Psicologia & AND & Nutrologia \\
\hline Oftalmologia & Psicologia & AND & Oftalmologia \\
\hline Ortopedia e Traumatologia & $\begin{array}{l}\text { Psicologia } \\
\text { Psicologia }\end{array}$ & $\begin{array}{l}\text { AND } \\
\text { AND }\end{array}$ & $\begin{array}{c}\text { Ortopedia } \\
\text { Traumatologia }\end{array}$ \\
\hline Otorrinolaringologia & Psicologia & AND & Otorrinolaringologia \\
\hline Patologia & Psicologia & AND & Patologia \\
\hline Patologia Clínica e Medicina Laboratorial & $\begin{array}{l}\text { Psicologia } \\
\text { Psicologia }\end{array}$ & $\begin{array}{l}\text { AND } \\
\text { AND }\end{array}$ & $\begin{array}{c}\text { Patologia AND Clínica } \\
\text { Medicina AND Laboratorial }\end{array}$ \\
\hline Pediatria & Psicologia & AND & Pediatria \\
\hline Pneumologia & Psicologia & AND & Pneumologia \\
\hline Psiquiatria & Psicologia & AND & Psiquiatria \\
\hline Radiologia e Diagnóstico por Imagem & $\begin{array}{l}\text { Psicologia } \\
\text { Psicologia }\end{array}$ & $\begin{array}{l}\text { AND } \\
\text { AND }\end{array}$ & $\begin{array}{c}\text { Radiologia } \\
\text { Diagnóstico AND Imagem }\end{array}$ \\
\hline Radioterapia & Psicologia & AND & Radioterapia \\
\hline Reumatologia & Psicologia & AND & Reumatologia \\
\hline Urologia & Psicologia & AND & Urologia \\
\hline
\end{tabular}

Figure 1. Collection 2: Search Strategies.

Inclusion and Exclusion Criteria of Matching Articles. The criteria of inclusion comprised in the publication have occurred in the period from 2005 to 2014, in Portuguese, and refer to behavior-analytic research papers focusing on the Health Psychology. Excluded were abstracts that: (a) repeated; (b) were incomplete (database does not provide a complete abstract); (b) were in other areas (Dentistry, Medicine, Nursing, Physical Education, etc.); (d) did not relate to work with behavior-analytic approach (radical behaviorism); (e) were not written by 
psychologists, although those addressed issues referred to the sub-area search; (f) did not correspond to the performance of Psychology; and $(\mathrm{g})$ were Brazilian authors without affiliation in their own country. The latter criterion was made possible by consulting the Currículo Lattes of researchers. Exclusion criteria were adapted from Ferreira, Soares, Orlandini, and Sabião (2008).

Registration of Gathered Data. In both collections, the descriptors and keywords have been entered first into the BVS-Psy Brazil Portal. Afterwards, the results were put into a Microsoft Excel spreadsheet and the abstracts contained in the Technical-Scientific Journals Psi Index, SciELO and LILACS were consulted for complete reading. The lists of those abstracts were printed, increasing the control of the studies in the selection to be analyzed. At this stage, the consultation of articles was made up in the cases in wich it was not possible to identify the criteria for inclusion and exclusion of the publication in the study solely by the abstract.

With the relevance of the material defined, the download of the full scientific article was carried out, as well as the reading of that in its entirety, with the subsequent integration of data collected in a spreadsheet developed in Microsoft Excel from the six study variables: Publishing Year, Type of Study, Objectives, Participants, Procedures and Conclusions.

Analysis of the Data. For the quantitative analysis, the SPSS software was used (Wagner,
2004) from the results of the variables "Publishing Year" and "Type of Study". The variables "Objectives", "Participants", "Procedures" and "Conclusions" were analyzed qualitatively, from the construction of a figure for each publication, summarizing the collected data.

\section{Results}

In total, 789 abstracts were read from the two procedures used in the three databases. In Collection 1, six behavior-analytic articles were retrieved and, in Collection 2, only a scientific article interface of interest was selected, belonging to the field of Psychiatry, totaling seven publications that represented $0.9 \%$ of total files found. Of those studies, 75\% were applied research, $12.5 \%$ experimental studies, and $12.5 \%$ conceptual studies, which denotes the predominance of Applied Behavior Analysis literature regarding issues related to the medical field.

According to the annual distribution of the scientific production of the sub-area in the decade studied, it was found that the publication occurred at a similar frequency at $12.5 \%$ per annum, ranging to $25 \%$ in 2010 and 2011, among the total of articles retrieved. The on-line database in which about half of the reviewed scientific articles referring to the Psi Index Technical-Scientific Journals, while $59.8 \%$ of the abstracts encountered have been obtained through LILACS. Figure 2 summarizes the general information of the seven articles.

\begin{tabular}{lccc}
\hline Author(s) & Magazine & ISSN & Publication Date \\
\hline Ferreira, Mendonça and Lobão & Estudos de Psicologia & $1982-0275$ & 2007 \\
Witter $^{\mathrm{a}}$ & Estudos de Psicologia & $1982-0275$ & 2008 \\
Wechsler and Amaral & Psicologia em Estudo & $1807-0329$ & 2010 \\
Vasconcellos, Rocha and Maciel & ConScientiae Saúde & $1677-1028$ & 2010 \\
Silva and Zakir & Estudos de Psicologia & $1982-0275$ & 2011 \\
Ceppi and Benvenuti & Revista de Psiquiatria Clínica & $0101-6083$ & 2011 \\
Brum and Carrara & Estudos de Psicologia & $1982-0275$ & 2012 \\
\hline
\end{tabular}

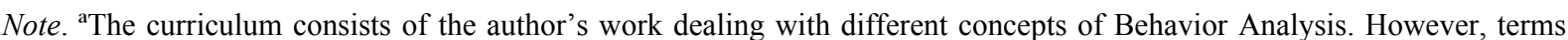
traditionally incompatible with a behavior-analytic view were used at work. The article was maintained in the analysis due to the author's several publications in the area and report the behavior-analytic approach.

Figure 2. Analytical-Behavioural Recovered Articles. 
The analysis of the objectives to which work done by behavior analysts in the Health Psychology sub-area reference are allowed to determine the permanence of the scientific approach by seeking control relationships between variables as the main feature of those productions. The descriptive method is also prevalent, as well as the use of experimental models in order to assist in the identification of functional relationships and an understanding of the issues applied. This happens because this approach of interpreting the description and explanation of behavioral phenomena as coincidences (Skinner, 1961).

The procedures adopted involved: the application of statistical tests, behavior records, mainly for self-monitoring, training for the installation and strengthening of repertoires, as well as training in contingency analysis and functional analysis. It was also used other enforcement procedures, i.e., relaxation, employment inventories and questionnaires for data collection and assessment procedures (pre and post-intervention), observing behaviors based on formulas, group-control organization and experimental group to allow comparisons between variables, treatment proposals analysis and empirical tools of functional analysis, electronic research and theory, with the interpretation done from a Skinner perspective.

Another important aspect to be mentioned refers to the variety of people and care protocols described in the work of the sub-area. That characteristic of scientific literature confirms the description of the field of health psychologist made by Miyazaki and Amaral (1995), which includes attention to various demands that are related to the health/disease continuum, attended to at different levels of this system. Kubo and Botomé (2001) complement the question by stating that the health condition is not a static phenomenon but a complex and dynamic process, psychologist demand knowledge of the network of interrelations that they determine probabilistically. Given those labor contingencies, the use of different instruments makes it crucial and necessary.
Based on the findings mentioned in the studies in question, it can be seen that they have considered the relevant applicability and usefulness of Behavior Analysis to the healthcare field, which brings a systems approach to understanding human behavior by analyzing the inclusion of functional analysis in those contexts. Still, such contributions should be more widespread and used, according to Ferreira et al. (2007).

\section{Discussion}

Based on the results, the limited number of interface articles retrieved through the BVSPsy Brazil was verified from the two elaborate procedures. It was observed that there was no consensus on the nomenclature of the subarea of the Health Psychology and that the descriptors that define it, such as "psychology of health" or "health psychology", are not included in the DeCS controlled vocabulary. If there are conceptual uncertainties, recurrent conditions the indexing process may already be being disregarded, with consequences to the quality of publications control proposed by the BVS. So researchers in this sub-area should seek alternatives for the development of more precise searches and resulting from more valid consensual bases (Kerbauy, 2002; Witter, 2008).

Keywords used by the Health Psychology researchers are not related to Behavior Analysis terminology or generic terms that will be named in that sub-field of Psychology, like the descriptors used in Collection 1. At the same time, the keywords related to specialties of Medicine retrieved works of an eminently biological nature, resulting in only a behavioranalytic article. Consequently, the exact descriptors employees retrieved only part of the national scientific literature produced with the bias of interest of that research.

On the other hand, the use of generic behavioral-analytic technical terms retrieved an overly large amount of work, but are not necessarily related to the sub-field of Health Psychology. The terms "functional analysis" and 
"behavioral therapy", also used in studies related to Health Psychology, e.g., are comprehensive and would require the establishment of precise criteria for the definition of research of characteristics belonging to the clinical and health fields.

The indexing itself made from generic terms of health makes it difficult to search the literature for professionals and students interested in different psychological approaches and, in the case of Behavior Analysis. Work with a psychoanalytic approach, e.g., are retrieved through the common behavioral-analytic studies descriptors. Although it is known that those are specific knowledge of Psychology scholars, a database that is guided in those particularities contribute to the systematization of the concepts, nomenclatures, classifications and areas. If the indexing process of a database linked to the WHO does not differentiate those aspects, it would be interesting to review the adequacy of planning that control of publications.

Due to the concern of behavior analysts in understanding the contingencies that produced certain health conditions, interventions are described in order to identify classes of antecedent stimuli, classes of responses and classes of consequent stimuli (or consequences) of behavioral patterns relevant to the occurrence of any disease. Functional analysis is characterized, therefore, as a tool for understanding behavioral events, based on the premise that environmental variables (independent variables) affect the behavior (dependent variable), depending on the interaction of the organism with its historic setting and the current context. According to Matos (1999), the radical behaviorist works with behaving within contexts, an aspect identified in all articles.

The behavior analyst, therefore, is responsible for scheduling contingencies through which aggregate goods and individual consequences will be obtained for a whole verbal community, which indicates the involvement of complex social behaviors and meta-contingencies related to public policies in health (Brum \& Carrara, 2012). Therefore, the focus is given in the articles analyzed for the operationaliza- tion of behaviors and the proposed inclusion of interventions from health programs.

Another common aspect addressed in the studies concern the relationship between coercion or aversiveness and changes in the health conditions of individuals. Aversive procedures are perceived as stressful situations, which elicit respondents and evoke operant that can compromise adherence to treatment and facilitate the installation and/or strengthening of repertoires of escape-avoidance. Due to that standard to cripple contact with positive reinforces linked to health, the psychologist must act in issuing appropriate instructions to the different conditions experienced in the modeling and coping repertoires to be issued by the patients in the face of aversive contingencies (Wechsler \& Amaral, 2010).

Silva and Zakir (2011) point out that researchers in the health field must have greater control of the registry of operands, with a greater number of participants and making use of different instruments for data collection in a way that promotes generalizations. That same criterion, however with therapeutic focus to ensure the maintenance and generalization of treatment in natural settings, is cited in the behavioral-analytic articles as essential for analyzing the effectiveness of the intervention and which shows the importance of evaluating the results, criteria defined by Kerbauy (2002) as key for vocational training.

The interweaving of concepts arising from different areas of knowledge was another feature of the sub-area found during that study, which requires the psychologist and/or researcher from the health field a different performance to propose interventions and research from languages and methodologies compatible to the medical field (Costa, 2010). To this end, training in undergraduate courses should be changed in order to enable the construction of interdisciplinary action plans (Witter, 2008).

Questions about more specific technical aspects, such as those relating to analytical criteria for the classification of publications according to the sub-fields of Psychology, as well as the terminology used by behavior analysts to compose 
the set of keywords for their scientific articles, is also pertinent to be emphasized from that review. It has been hypothesized that the health care researchers produce knowledge, but are probably not always worried about the access of the community to that production, hypothesis raised by the discrepancy between the stated terms as keywords in found work and the terms of the DeCS used in the indexing.

Analyzing the results of that study, it is understood that the academic and scientific community must facilitate professionals' and students' access to technical and scientific information, which can be done in two ways. The first is by increasing the number of publications indexed in the open access databases and in Portuguese. In academia, publications in journals with restricted access, along with international, are widely supported as they often rely on an assessment that gives them greater credibility and, consequently, greater appreciation of the curriculum of the researchers. However, the scope of the objective of contributing to the work of professionals may be compromised because most psychologists do not have access to that knowledge.

Another means of facilitating access to the knowledge produced, even in the open-access databases, is by the approximation of analysis criteria of those materials by professionals of Information Science and Behavior Analysis, from the revision of the exact descriptors used in controlled vocabularies. Professionals and psychology students should be aware of those vocabularies, which guide the indexing process and, therefore, the retrieval of scientific production, with concepts and synonyms referring to a descriptor.

One wonders: Should Behavior Analysis adapt its specific terminology and language for medical settings? Would it be more coherent and viable an adaptation of the terminology used in that approach of Psychology to the health field or otherwise? What are the contributions of the suggested approach between Medicine, Information Science and Behavior Analysis? Would the strategies allow for the Behavior Analysis to increase the visibility of their products in freely accessible on-line databases and, consequently, favor "systematic interventions", according to its focus?

This article denotes the complexity of the drafting of systematic review works, the need for the dissemination of scientific knowledge for the academic and professional community as a whole, the execution of studies on the indexing processes of scientific publications in on-line databases and the importance of controlled vocabulary descriptors for proper retrieval. The databases can help in systematizing an area of knowledge, depending on how they are organized.

\section{Concluding Remarks}

Despite the terminological inconsistency of Health Psychology, the barriers pertaining to the very structure of the BVS-Psy Brazil and the limitations of that inquiry, the results suggested the relevant applicability of Behavior Analysis to healthcare due mainly from the research in that psychological approach being built on control variables and subject to replication (Rolim, Rocha, \& Moraes, 2009). It is therefore understood that this psychological system can contribute to national productions presenting a differentiated approach and more consistent with the demands of the field. Consequently, it encourages that behavior analysts translate health care literature for the theoretical, experimental and applied benchmarks of their approach.

It should be pointed out that, from this review, a limited number of research behavior analysts who work with issues related to the health field was retrieved, despite that those professionals may be publishing in restricted access databases or even in open access databases, but such researches should be recovered from different search paradigms than were used in that investigation. It isn't possible to systematically assess any scientific Behavior Analysis in health care based on that study, nevertheless the methodology adopted, encompassing open access databases, was valid 
to indicate a need that can directly interfere with the performance of behavior analysts in health: the need for knowledge accessible for everyone.

It was found that the construction of an effective control of national scientific production in Psychology from the BVS-Psi Brazil will require exhaustive research regarding the indexing processes in that database, with the appropriate revision of the criteria for grouping the studies according to the DeCS vocabulary. To this end, the development of collaborative and interdisciplinary work by professionals in Information Science, Medicine and Psychology is suggested. Field research that examines the possible correlation between the sources of consulted information and the effectiveness of interventions in Health Psychology, in addition to studies analyzing the quality of scientific literature published in open access databases that can also contribute to the theme and give conditions to the systematic interventions.

\section{References}

Brum, M. M., \& Carrara, K. (2012). História individual e práticas culturais: Efeitos no uso de preservativos por adolescentes. Estudos de Psicologia (Campinas), 29(1), 689-697. doi:10.1590/ S0103-166X2012000500005

Castro, E. K. de., \& Bornholdt, E. (2004). Psicologia da Saúde x Psicologia Hospitalar: Definições e possibilidades de inserção profissional. Psicologia: Ciência e Profissão, 24(3), 48-57. doi:10.1590/S1414-98932004000300007

Ceppi, B., \& Benvenuti, M. (2011). Análise funcional do comportamento autolesivo. Revista de Psiquiatria Clínica, 38(6), 247-253. doi:10.1590/S0101-60832011000600006

Costa, A. B., \& Zoltowski, A. P. C. (2014). Como escrever um artigo de revisão sistemática. In $\mathrm{S}$. H. Koller, M. C. P. de P. Couto, \& J. V. Hohendorff (Eds.), Manual de produção cientifica (pp. 55-70). Porto Alegre, RS: Penso.

Costa, Á. L., Jr. (1997). Psicologia da Saúde: Uma proposta de renovação de modelos clínicos tradicionais. Revista Insight-Psicoterapia, 7(80), 24-27.
Costa, Á. L., Jr. (2010, May). Psicologia da Saúde: Pesquisa e intervenção profissional. Paper presented at the meeting of I Congresso de Psicologia e Análise do Comportamento, Londrina, PR, Brazil. Retrieved from http:// www.uel.br/eventos/cpac/pages/edicoesanteriores/i-cpac.php

Costa, Á. L., Jr., Doca, F. N. P., Araújo, I., Martins, L., Mundim, L., Penatti, T., \& Sidrim, A. C. (2012). Preparação psicológica de pacientes submetidos a procedimentos cirúrgicos. Estudos de Psicologia (Campinas), 29(2), 271-284. doi:10.1590/S0103-166X2012000200013

Federal Council of Medicine. (2012, December 21). Resolução CFM n $n^{\circ}$ 2.005, de 21 de dezembro de 2012. Dispõe sobre a nova redação dos Anexos II e III da Resolução n. 1.973 de 2011. Diário Oficial da União, Seção 1, 937940. Brasília, DF: Author. Retrieved from http://www.portalmedico.org.br/resolucoes/ CFM/2012/2005_2012.pdf

Federal Council of Psychology. (2006). A História da Psicologia Hospitalar [Special issue]. Psicologia: Ciência e Profissão - Diálogos. Saúde e Psicologia: Os desafios teóricos e práticos e as conquistas no cuidado com o sujeito, 3(4), 20-25. Retrieved from http://site.cfp.org.br/wpcontent/uploads/2007/02/dialogos_4.pdf

Ferreira, E. A. P., Mendonça, M. B., \& Lobão, A. C. (2007). Adesão ao tratamento da urticária crônica. Estudos de Psicologia (Campinas), 24(4), 539-549. doi:10.1590/S0103166X2007000400013

Ferreira, R. E., Soares, M. R. Z., Orlandini, T. F., \& Sabião, L. S. (2008, November). Mulheres com câncer de mama: Análise de produção cientifica a partir de resumos publicados entre 2000 e 2008. Paper presented at the meeting of II Encontro Paranaense de Análise do Comportamento, Curitiba, PR, Brazil. Retrieved from http://www.fappr.pr.gov.br/arquivos/File/projetos08-2008/14124_Anais.pdf

Galvão, C. M., Sawada, N. O., \& Trevizan, M. A. (2004). Revisão sistemática: Recurso que proporciona a incorporação das evidências na prática da Enfermagem. Revista Latino-Americana de Enfermagem, 12(3), 549-556. doi:10.1590/ S0104-11692004000300014

Glueckauf, R. (1999). Interdivisional Healthcare Committee: Speaking with one voice on crosscutting issues in Health Care Psychology. Jour- 
nal of Clinical Psychology in Medical Settings, 6(2), 171-181. doi:10.1023/A:1026292110347

Gorayeb, R., \& Guerrelhas, F. (2003). Sistematização da prática psicológica em ambientes médicos. Revista Brasileira de Terapia Comportamental e Cognitiva, 5(1), 11-19. Retrieved from http:// pepsic.bvsalud.org/scielo.php?pid=S1517$55452003000100003 \&$ script=sci_arttext

Jenkins, C. D. (2007). Construindo uma saúde melhor: Um guia para a mudança de comportamento (A. P. Fajardo, Trans.). São Paulo, SP: Artmed. (Original work published 2003)

Johnston, J. M. (1996). Distinguishing between applied research and practice. The Behavior Analyst, 19(1), 35-47. Retrieved from http://www.ncbi.nlm.nih.gov/pmc/articles/ PMC2733595/pdf/behavan00019-0036.pdf

Kaplan, R. M. (1990). Behavior as the central outcome in health care. American Psychologist, 45(11), 1211-1220. doi:10.1037/0003-066X.45.11.1211

Kerbauy, R. R. (2002). Comportamento e saúde: Doenças e desafios. Psicologia USP, 13(1), 1128. doi:10.1590/S0103-65642002000100002

King, M. C. (2006). Preparing Psychology and psychologists for new health care markets. Canadian Psychology, 47(1), 51-56. doi:10.1037/ h0087044

Kubo, O. M., \& Botomé, S. P. (2001). Formação e atuação do psicólogo para o tratamento em saúde e em organizações de atendimento à saúde. Interação em Psicologia, 5, 1-14. doi:10.5380/psi. v5i1.3319

Luna, S. V. de. (2007). Planejamento de pesquisa: Uma introdução. São Paulo, SP: Editora da Pontifícia Universidade Católica de São Paulo.

Matarazzo, J. D. (1980). Behavioral Health and Behavioral Medicine: Frontiers for a new Health Psychology. American Psychologist, 35(9), 807817. doi:10.1037/0003-066X.35.9.807

Matarazzo, J. D. (1982). Behavioral Health's challenge to academic, scientific, and professional Psychology. American Psychologist, 37(1), 1-14. doi:10.1037/0003-066X.37.1.1

Matos, M. A. (1999). Com o que o Behaviorismo Radical trabalha. In R. A. Banaco (Ed.), Sobre comportamento e cognição: Questões teóricas, metodológicas e a formação em Análise do Comportamento e Terapia Cognitivista ( $2^{\text {nd }} \mathrm{ed}$, pp. 45-53). São Paulo, SP: ARBytes.
McNamara, J. R. (1981). Some unresolved challenges facing Psychology's entrance into the health care field. Professional Psychology, 12(3), 391399. doi:10.1037/0735-7028.12.3.391

Ministry of Education, Coordination for the Improvement of Higher Level Personnel. (2013). Atualiza o WebQualis da Área de Psicologia referente ao ano de 2011 (Comunicado n. 001/2013). Brasília, DF: Author. Retrieved from https:/www.capes.gov.br/images/ stories/download/avaliacao/Comunicado012013webqualis-psic.pdf

Miyazaki, M. C. de O. S., \& Amaral, V. L. A. R. (1995). Instituições de saúde. In B. Rangé (Ed.), Psicoterapia comportamental e cognitiva: Pesquisa, prática, aplicações e problemas (pp. 235244). Campinas, SP: Editorial Psy.

Packer, A. L. (2005). A construção coletiva da Biblioteca Virtual em Saúde. Interface Comunicação, Saúde e Educação, 9(17), 249272. doi:10.1590/S1414-32832005000200004

Pellizzon, R. de F. (2004). Pesquisa na área da saúde: 1. Base de dados DeCS (Descritores em Ciências da Saúde). Acta Cirúrgica Brasileira, 19(2), 153-163. doi:10.1590/S010286502004000200013

Pomerleau, O. F. (1979). Behavioral Medicine: The contribution of the Experimental Analysis of Behavior to medical care. American Psychologist, 34(8), 654-663. doi:10.1037/0003066X.34.8.654

Regional Council of Psychology in the $8^{\text {th }}$ Region. (2010). Levantamento do perfil profissional e das condições de trabalho dos psicólogos do Paraná - CRP-08. Retrieved from http://www. portal.crppr.org.br/download/265.pdf

Reid, D. H. (1991). Technological behavior analysis and societal impact: A human services perspective. Journal of Applied Behavior Analysis, 24(3), 437-439. doi:10.1901/ jaba.1991.24-437

Rolim, G. S., Rocha, R. A. de S., \& Moraes, A. B. A. (2009). O ensino e a pesquisa em Odontopediatria: $\mathrm{O}$ difícil controle de variáveis. $\mathrm{Mu}$ danças - Psicologia da Saúde, 17(1), 17-21. doi:10.15603/2176-1019/mud.v17n1p17-21

Silva, M. E. M., \& Zakir, N. S. (2011). Controle instrucional e relaxamento como preparo psicológico pré-cirúrgico para portadores de cardiopatia. Estudos de Psicologia (Campinas), 28(3), 371379. doi:10.1590/S0103-166X2011000300009 
Skinner, B. F. (1961). The concept of the reflex in the description of behavior. In B. F. Skinner, Cumulative Record [Enlarged edition] (pp. 319-346). New York: Appleton-Century-Crofts.

Smith, T. W., Kendall, P. C., \& Keefe, F. J. (2002). Behavioral Medicine and Clinical Health Psychology: Introduction to the special issue, a view from the decade of behavior. Journal of Consulting and Clinical Psychology, 70(3), 459-462. doi:10.1037/0022-006X.70.3.459

Straub, R. O. (2005). Psicologia da Saúde: Uma abordagem biopsicossocial. Porto Alegre, RS: Artmed.

Vasconcellos, M., Rocha, M. C. D. O., \& Maciel, V. H. (2010). Revisão teórica sobre depressão pela Análise do Comportamento e alguns manuais psiquiátricos. ConScientiae Saúde, 9(4), 719725. doi:10.5585/conssaude.v9i4.2145

Volpato, G. L. (2007). Ciência: Da filosofia à publicação. São Paulo, SP: Cultura Acadêmica.
Wagner, M. B. (2004). SPSS passo a passo: Statistical package for the social sciences. Versão 20.0. Caxias do Sul, RS: Editora da Universidade de Caxias do Sul.

Wechsler, A. M., \& Amaral, V. L. A. R. (2010). Dizer $\mathrm{x}$ fazer de mães e filhos em exame médico. Psicologia em Estudo, 15(1), 55-63. doi:10.1590/ S1413-73722010000100007

Witter, G. P. (2008). Psicologia da Saúde e produção científica. Estudos de Psicologia (Campinas), 25(4), 577-584. doi:10.1590/S0103166X2008000400012
Recebido: 28/01/2015

$1^{a}$ revisão: 09/07/2015

$2^{a}$ revisão: $26 / 08 / 2015$

Aceite final: 27/08/2015 